\title{
INTERNATIONALIZATION OF EDUCATIONAL ACTIVITY THROUGH LINGVOCULTURAL COMPETENCE OF STUDENTS OF HIGHER EDUCATIONAL ESTABLISHMENTS AS AN INDICATOR OF QUALITY OF EDUCATION
}

\author{
A.A. Podgorbunskikh, aapodgorbunskikh@mail.ru \\ Shadrinsk State University, Shadrinsk, Russian Federation
}

\begin{abstract}
The article discusses the status of internationalization, of the definition "lingvocultural study", the parity of the concepts: "proficiency" and "competence". The author defines the central concept "lingvocultural proficiency" on the basis of a multidimensional analysis. This article indicates the problem of students of higher educational establishments lingvocultural proficiency as a result of their linguistic and cultural training in professional sphere.

External internationalization of the educational activity of the university is considered as a priority. The article also considers the internationalization of educational activities in the process of forming the lingvocultural competence of students. The authors point out the general segments of the educational and lingvocultural environment of the higher educational institution. The article contains information on characteristics of the educational environment of the university and internationalization as an indicator of education quality.

Keywords: internationalization, lingvocultural study, proficiency, competence, lingvocultural proficiency, lingvocultural competence, lingvocultural environment, innovative lingvocultural environment, international cooperation.
\end{abstract}

Introduction. In the modern world developed states form a policy of stability in the education system and the implementation of innovative processes. Normative documents of the Russian Federation in the sphere of education are Federal Law of the Russian Federation on Education, the national doctrine of education and others state the priority of the following aspects of institutions' activity of higher professional education. These are the unity of the educational space of the Russian Federation, the quality of higher professional education, the basis for an objective assessment of the activities of educational institutions implementing educational programs of higher professional education, recognition and establishment of equivalence of documents of foreign states on higher professional education. We share the mind the quality of education is the conformity of education (as a result, as a process, as a social system) to various needs, interests of personality, of society, of State [14]. It is also system whole of hierarchical organized, social significant essential behaviors of education (as a result, as a process, as a social system). In modern pedagogical studies, it is important to take into account the multicultural aspects of university training, research is being conducted in the sphere of multicultural education and cultural studies of education. However, the issues of the formation of a special type of intercultural competence (lingvocultural) have not received the proper scientific attention.

The internationalization of higher education tends to expand and accelerate, is accompanied by an increase in the homogeneity and continuity of the world educational space, the formation of integrated mega-regional spaces, and the convergence of the properties and parameters of national educational spaces. In the process of internationalization, the state and universities are purposefully realizing their own interests, entering into contradictory relations. The main is the contradiction between the financial and regulatory dependence of universities on the state and the desire of universities to autonomy $[3,5,8,20]$.

Definitions. To implement a multidimensional study of the essence of this concept we consider to determine the status of the central concepts for our research. These are "linguoculturology" and "competence" and on the basis of complex scientific reflection to determine the essence of the concept of "linguistic cultural competence" of interest to us, while considering the specifics of linguistic and cultural training of students in the university.

Competence is defined as the ability of an individual to interact effectively with surrounding people in a system of interpersonal rela- 
tionships $[6,9,15]$ in psychological research. In the pedagogical interpretation competence can be identified as the possession by the teacher of the necessary amount of knowledge, skills and skills that determine the formation of his pedagogical activity, pedagogical communication and the personality of the teacher as the bearer of certain values, ideals and pedagogical consciousness [16]. In addition, competence is understood as a special type of organization of subject-specific knowledge, allowing to make decisions more effectively in the relevant sphere of activity [7]. In the sphere of education we can interpret competence as the quality of a person who completed the formation of a certain stage expressed in the readiness (ability) on its basis to a successful (productive, effective) activity taking into account its social significance and social risks that may be associated with it. Actually, competence is regarded as a self-realized ability of a person, based on acquired knowledge, intellectual and life experience, values and inclinations, which he developed as a result of cognitive activity and educational practice. This interpretation seems to us the most acceptable, therefore in our study we will stick to it. The terminological problem associated with the scientific reflection of the essence of the concept of "competence" is complicated at the present time by functioning in the scientific theory of the conjugate notion of "competence". Discussions about the relationship of which are continuing even now.

Internationalization is a formation of intercultural and international measuring in higher education directed on the improvement of preparation for the specialists' quality [19]. Internationalization as the key aspect of the development of Russian education understood as the process of providing educational services that have an international dimension and what is happening at the national, sectorial and institutional level [10]. A generalized analysis of the research in this area has allowed us to establish that competence is seen as a unity of knowledge, professional experience, ability to act and the behavior of the individual, determined by the purpose, the situation's predetermination and position. Competence refers to a given situation, combines and dynamically combines the constituent elements of it to adapt to the requirements of the job. We believe that in the most generalized form it is possible to define competence as a property (quality), and competence can be considered as possession of this property that is manifested in professional activity. The term "competence" is logical to use to describe a specialist in his professional activity, and "competence" is to designate a basic property (quality) that makes a specialist "potentially" competent. One of the most important issues of this scientific direction is the definition of the nomenclature of professionally relevant competencies, which should be determined with reliance on the "professional" context, when specific goals are set to meet the needs of society in a particular sphere of life. The consequence of solving this issue is the emergence and description in scientific research of various types of competencies and competences. A notion of "professional competence", which is interpreted as the ability to apply knowledge, skills, successfully act on the basis of practical experience in solving problems of a general kind, also in a certain professional field. It is significant for our study. Personal ability of a specialist (employee) to solve a certain class of professional tasks.

The competence of a specialist with a higher education is also considered as a desire and ability (willingness) manifested in practice to realize his potential (knowledge, skills, experience, personal qualities, etc.) for successful creative (productive) activity in the professional and social sphere. The specialist realizes it social importance and personal responsibility for the results of this activity, the need for its continuous improvement (Yu.G. Tatur) [17].

The subject of our study is the formation of one of the components of the complex pedagogical phenomenon of communicative competence the linguistic and cultural competence of university students - it is necessary to present some research positions in relation to the interpretation of the concept of "communicative competence" which is interpreted as:

- knowledge and skills necessary to understand others and generate their own speech behavior programs that are adequate to the purposes, spheres, situations of communication and includes: knowledge of the basic concepts of speech linguistics (speech knowledge) - styles, types, ways of linking sentences in the text and etc. Skills of text analysis, and, finally, the actual communication skills - the skills and skills of speech communication in relation to various spheres and situations of communication, taking into account the addressee, aims;

- readiness and ability to carry out foreignlanguage communication in certain program 


\section{Теория и методика профессионального образования}

limits, as well as education, education and development of the person's personality by means of a foreign language;

- foreign interpersonal and intercultural communication with native speakers in a standard limit.

In the course of our research we (following R. Milrud) have come to the conclusion that communicative competence is the demonstrated region (areas) of successful communicative activity on the basis of acquired means and strategies of verbal communication, backed up by language skills and speech skills $[11,12]$. An analysis of scientific pedagogical literature has showed that competence is a complex, multicomponent, interdisciplinary notion defined by a variety of different definitions. The descriptions of the content of this notion are of a non-strict nature and differ in volume, composition, semantic and logical structure. Signs of the manifestation of competence are most often described using the terms "efficiency", "adaptability", "achievement", "success", "understanding", "performance", "possession", "quality" and "quantity". Further it is necessary to dwell on the question of the functioning in the modern problem field of linguodidactics of the term "linguoculturology". This term is important to us. Nowadays linguoculturology is positioned as a new scientific direction, and not just a fusion of two interacting sciences - linguistics and cultural studies, as an interdisciplinary, independent branch with its own aims, objectives, object and subject of research.

Let's state the most widespread and wellestablished interpretations of the term "linguoculturology". This concept is treated as:

1) the humanitarian field of science, which studies culture, material and spiritual, expressed in language and language processes;

2) a complex scientific discipline that studies the interrelation and interaction of culture and language in its functioning;

3) part of the science of man, which is oriented, on the one hand, to the human factor in the language, on the other - to the language factor in man;

4) science, which is focused on the current state and functioning of language and culture;

5) part of ethnolinguistics, which is devoted to the study and description of correspondence of language and culture in their synchronous interaction and exploring living communicative processes and the connection of linguistic expres- sions used in them with the synchronously acting mentality of the people (literary, philosophical, religious, folklore discourses as sources of cultural information);

6) the aspect of linguodidactics, which considers the problems of interaction between culture and language in the process of its functioning, as well as description and teaching.

In our work we will adhere to the interpretation of linguoculturology as a complex scientific discipline of the synthesizing type, directly related to the study of culture, which studies in a certain way a selected and organized set of cultural values, explores the living communicative processes of generation and perception of speech, the experience of the linguistic personality and national Mentality, provides a systematic description of the language "picture of the world" and ensures the implementation of educational, educational and intellectual Learning tasks.

Models. The practice of intercultural communication now puts forward, as an educational imperative, the provision that the effective maintenance of various intercultural contacts and forms of communication is possible provided that the vocational training in the relevant fields is reoriented to the study of language and culture.

This is possible in the sphere of appropriate linguistic and cultural training of future specialists - students of a higher educational establishments, whose main features at the present stage are: orientation of the language training of university students for functional knowledge of the corresponding foreign language. These are also a formation of complex knowledge about forms of behavior, history, psychology, culture of partners in communication (representatives of other linguoculture) and formation of students knowledge of the mechanism of the process of communication including communication in the intercultural sphere.

Internationalization provides the learning process Means of access and operation of authentic and educational information that is foreign to other languages, means of computer-mediated communication in a foreign language, tools for socialization in a foreign culture and remote study of linguistic and cultural realities [2, 18]. The result of linguocultural training of students in the university is linguistic and cultural competence, the process of formation of which is the subject of our study. We mean using the termlingvocultural competence the integrative quality of a person including knowledge, skills, 
skills related to the selection, assimilation, processing, transformation and use in practice of information about linguistic culture, the general norms, rules and traditions of verbal and nonverbal communication within this linguistic culture. The lingvocultural competence of students of higher educational establishments is interpreted by us as an integrative quality of the specialist, reflecting the readiness and the ability to understand and interact with representatives of another linguistic cultural society on the basis of mastering knowledge of another linguistic culture and socionormative communicative experience with the goal of their implementation in various spheres of professional activity.

The structure of linguocultural competence of students of a higher educational establishments is a specially organized set of components and connections between them. From the positions of the system approach structural components are identified on the basis of analysis of structural links within the system. It is a subcompetent analysis of the essence of linguistic cultural competence, and functional ones that based on the analysis of the corresponding functional links according to the following criteria: the functions of foreign-language intercultural communication, the degree of synchronization in the assimilation of another linguistic culture, the level of dialogization of intercultural interaction in the professional sphere. We consider that to determine the components of linguistic and cultural competence of university students, it is first of all necessary to determine its substantive and procedural fillability. In accordance with this provision, we believe that the linguistic and cultural competence of university students has a bicomponent structure that includes cognitive-conceptual and communicative-activity components, which include relevant subcomponents. Given the current trends in structuring the composition of complex pedagogical phenomena, it is advisable to present the components and subcompetencies that are part of the linguistic and cultural competence of university students in the form of a cluster of competences which is understood as a set of closely related competences (usually three to five). Functions are an external manifestation of the properties of the object in the system of relations. And they determine the specificity of linguocultural competence.

Functional components are the basic links between the initial state of the structural components of the system and the end result of its func- tioning. Functional components of linguocultural competence reflect the dialectical, multilevel and dynamic nature of this phenomenon, its integral, evolving nature, therefore its structural components must be presented as necessary and sufficient for its preservation and development. The stability of the functional components of linguocultural competence is determined by their relationship to the structural components and to each other.

Conclusion. The analysis allowed us to distinguish the following functional components of the linguistic and cultural competence of the students of higher educational establishments:

- emotional-evaluative component assumes the ability of students to express opinions, feelings, assessments, emotions in relation to manifestations of another linguoculture;

- information and communication component means the ability to carry out the process of transmitting and receiving information in situations of intercultural and occupational orientation;

- regulatory and management component is manifested in the ability of students to influence the behavior of representatives of other linguoculture in the process of intercultural communication by regulating their own behavior and mutual "adjustment" of actions.

Structural and functional components of the linguistic and cultural competence of the university students examined by us allow us to judge this pedagogical and linguocultural phenomenon as a complex entity with a multicomponent structure. The integrity is ensured by their interconnection and interdependence. Through lingvocultural competence of students of higher educational establishments it can see internationalization of educational activity.

Internationalization, viewed as an organizational adaptation, requires its articulation by the leadership while simultaneously institutionalizing a strategic planning process that is representative and participative in that it recognizes and utilizes the power of the culture within which it occurs [1, 13]. Recruiting foreign students, creating preparatory faculties, distance learning, expanding the range of additional educational services play an important role in the internationalization of Russian universities. These are an implementation of joint programs on the basis of a foreign university, opening of a foreign branch of a Russian university, promotion abroad of the results of scientific and educational activi- 


\section{Теория и методика профессионального образования}

ties, an implementation of projects for the development of teachers abroad. These are also an attraction of foreign grants and scholarships and a participation in international networks and alliances of universities on the basis of consortia [4].

Nowadays there is a great interest of scientists to the problem of interaction between language and culture, which is connected with the birth of a new approach to language research in the framework of an anthropological paradigm and a new discipline - linguoculturology. There is aneed to further develop the theory of this direction and popularize linguistic cultural values, including In the paradigm of vocational education. The internalization is possible through the lingvocultural competence of the students of the highschool and it is also an indicator of high quality of education.

\section{References}

1. Bartell M. Internationalization of Universities: a University Culture-based Framework. Higher Education, 2003, vol. 45, no. 1, pp. 43-70. DOI: $10.1023 / \mathrm{A}: 1021225514599$

2. Byram M. Assessing Intercultural Competence in Language Teaching. Sprogforum, 2004, vol. 6, no. 18, pp. 8-13.

3. De Wit H. Internationalization of Higher Education in the United States of America and Europe: A Historical, Comparative and Conceptual Analysis. Westport, Greenwood Press Publ., 2002.

4. Elkina A.S. Internatsionalizatsiya deyatel'nosti vuzov kak tendentsiya razvitiya sistem vysshego obrazovaniya. Diss. kand. ped. nauk [Internationalization of the Activities of Universities as a Trend in the Development of Higher Education Systems. Diss. Doct. (Pedagogy)]. Volgograd, 2010. $201 \mathrm{p}$.

5. Enders J. Higher Education, Internationalization and the Nation State: Recent Developments and Challenges to Governance Theory. Higher Education, 2004, no. 47 (3), pp. 361-382. DOI: 10.1023/B:HIGH.0000016461.98676.30

6. Golovin S.Yu. Slovar' prakticheskogo psikhologa [Dictionary of Practical Psychologist]. Minsk, Kharvest Publ., 2001. 427 p.

7. Kholodnaya M.A. Psikhologiya intellekta: paradoksy issledovaniya [Psychology of the Intellect: the Paradoxes of Research]. St. Petersburg, Piter Publ., 2002. 272 p.

8. Knight J. Internationalization Remodeled: Definition, Approaches and Rationales. Journal of
Studies in Intercultural Education, 2004, no. 8 (1), pp. 5-31. DOI: 10.1177/1028315303260832

9. Lefransua G. Prikladnaya pedagogicheskaya psikhologiya [Applied Pedagogical Psychology]. St. Petersburg, PRAYM-EVROZNAK Publ., 2003. 416 p.

10. Lysenko E. Internationalization as a Key Aspect of Development of High Education. European Review of Social Sciences, 2015, vol. 2, no. 1 , pp. 41-46.

11. Maslova V.A. Lingvokul'turologiya [Lingvo Cultural Studies]. Moscow, Akademiya Publ., 2004. 208 p.

12. Mil'rud R.P. Kommunikativnaya kompetentsiya i kommunikativnaya kompetentnost': Chem otlichayutsya eti terminy [Communicative Competence and Communicative Competency: How do These Terms Differ?]. Available at: www.englishteachers.ru/Dr.Millrood'sSchoolofM ethodology (accessed 25.04.2017).

13. Schoorman D. What Really do We Mean by "Internationalization?" Contemporary Education, 2000, vol. 71, no. 4, pp. 5-11.

14. Selezneva N.A. Slovar' soglasovannykh terminov $i$ opredeleniy $v$ oblasti obrazovaniya gosudarstv-uchastnikov Sodruzhestva Nezavisimykh Gosudarstv [Glossary of Agreed Terms and Definitions in the Field of Education of the StatesParticipants of the Commonwealth of Independent States]. Moscow, MISiS Publ., 2012. 244 p.

15. Smirnov A.G. Praktikum po obshchey psikhologii [Practical Work on General Psychology]. Moscow, Institut Psikhoterapii Publ., 2002. $224 \mathrm{p}$.

16. Smirnov S.D. Pedagogika i psikhologiya vysshego obrazovaniya: ot deyatel'nosti $k$ lichnosti [Pedagogy and Psychology of Higher Education: from Activity to Personality]. Moscow, Akademiya Publ., 2001. 304 p.

17. Tatur Yu. G. [Competence in the Structure of the Quality Model of Specialist Training]. Higher Education Today, 2004, no. 3, pp. 20-26. (in Russ.)

18. Tumalev A.V. [The Role of the Virtual Environment in the Development of the Professional Competence of a Specialist]. Global'nyy ekonomicheskiy krizis: realii i puti preodoleniya: sbornik nauchnykh statey [The Global Economic Crisis: Realities and Ways to Overcome: a Collection of Scientific Articles]. St. Petersburg, Institute Biznesa i Prava Publ., 2009, pp. 515-521. (in Russ.)

19. Vazhnichaya E.M., Devyatkina T.A., Devyatkin A.E., Lutsenko R.V., Lugovaya L.A. 
[Internationalization of Higher Education: General Concepts and Some Errors Associated with Them]. World of Medicine and Biology, 2013, no. 2-1 (37), pp. 33-35. (in Russ.)
20. Yang R. University Internationalization: Its Meanings, Rationales and Implications. Intercultural Education, 2002, no. 13 (1), pp. 89-95. DOI: $10.1080 / 14675980120112968$

Received 30 April 2017

УДК $378.016+81 ' 1$

DOI: $10.14529 /$ ped170308

ББК Ч448.44 + Ш100.0

\title{
ИНТЕРНАЦИОНАЛИЗАЦИЯ ОБРАЗОВАТЕЛЬНОЙ ДЕЯТЕЛЬНОСТИ ПОСРЕДСТВОМ ЛИНГВОКУЛЬТУРНОЙ КОМПЕТЕНТНОСТИ СТУДЕНТОВ ВУЗА КАК ПОКАЗАТЕЛЬ КАЧЕСТВА ОБРАЗОВАНИЯ
}

\author{
А.А. Подгорбунских \\ Шадринский государственный педагогический университет, г. Шадринск
}

\begin{abstract}
В статье представлена информация об интернационализации, об определении статуса понятия «лингвокультурология», соотношении понятий «компетентность» и «компетенция». На основе многоаспектного анализа автором определена сущность понятия «лингвокультурная компетентность». Рассматривается проблема формирования лингвокультурной компетентности студентов как результата лингвокультурной подготовки в профессиональной сфере.

Внешняя интернационализация образовательной деятельности вуза рассматривается как приоритетное направление. В статье также интерпретируется интернационализация образовательной деятельности в процессе формирования лингвокультурной компетентности студентов. Автор указывает на общие сегменты образовательной и лингвокультурной среды в высшем учебном заведении. В статье изложена информация о характеристиках образовательной среды вуза и интернационализации в качестве показателя качества образования.

Ключевые слова: интернационализация, лингвокультурология, компетентность, компетенция, лингвокультурная компетентность, лингвокультурная компетеничя, лингвокультурная среда, инновационная лингвокультурная среда вуза, международное сотрудничество.
\end{abstract}

\section{Лumepamypa}

1. Bartell, M. Internationalization of universities: a university culture-based framework / M. Bartell // Higher Education. - 2003. - T. 45, № 1. - P. 43-70.

2. Byram, M. Assessing Intercultural Competence in Language Teaching / M. Byram // Sprogforum. - 2004. - Vol. 6, № 18. - P. 8-13.

3. De Wit, H. Internationalization of higher education in the United States of America and Europe: A historical, comparative and conceptual analysis / H. De Wit. - Westport, CT: Greenwood Press, 2002.

4. Елкина, А.С. Интернационализация деятельности вузов как тенденция развития систем выстего образования: дис. ... канд. эконом. наук / А.С. Елкина. - Волгоград, 2010. - 201 c.

5. Enders, J. Higher education, internationalization and the nation state: Recent developments and challenges to governance theory // Higher Education. - 2004. - № 47(3). - P. 361-382.

6. Словарь практического психолога / сост. С.Ю. Головин. - Минск: Харвест, 2001. -427 c.

7. Холодная, М.А. Психология интеллекта: парадоксы исследования / М.А. Холодная. СПб.: Питер, 2002. - 272 c. 


\section{Теория и методика профессионального образования}

8. Knight, J. Internationalization remodeled: Definition, approaches and rationales / J. Knight // Journal of Studies in Intercultural Education. - 2004. - № 8(1). - P. 5-31.

9. Лефрансуа, Г. Прикладная педагогическая психология / Г. Лефрансуа. - СПб.: ПРАЙМЕВРОЗНАК, 2003. - $416 \mathrm{c}$.

10. Lysenko, E. Internationalization as a key aspect of development of high education / E. Lysenko // Европ. обозрение обществ. наук . - 2015. - Vol. 2, № 1. - P. 41-46.

11. Маслова, В.А. Лингвокультурология / В.А. Маслова. - М.: Академия, 2004. - 208 с.

12. Мильруд, Р.П. Коммуникативная компетенция и коммуникативная компетентность: Чем отличаются эти термины / Р.П. Мильруд. - www.englishteachers.ruDr.Millrood'sSchoolofMethodology.

13. Schoorman, D. What really do we mean by "internationalization?" // Contemporary Education. - 2000. - Vol. 71, № 4. - P. 5-11.

14. Словарь согласованных терминов и определений в области образования государствучастников Содружества Независимьх Государств / под науч. ред. д-ра техн. наук, проф. Н.А. Селезневой. - М.: МИСиС, 2012. - 244 c.

15. Смирнов, С.Д. Педагогика и психология высшего образования: от деятельности к личности / С.Д. Смирнов. - М.: Академия, 2001. - 304 с.

16. Смирнов, А.Г. Практикум по общей психологии / А.Г. Смирнов. - М.: Ин-т психотераnuи, 2002. $-224 \mathrm{c}$.

17. Татур, Ю.Г. Компетентность в структуре модели качества подготовки специалиста / Ю.Г. Татур // Высш. образование сегодня. - 2004. - № 3. - С. 20-26.

18. Тумалев, А.В. Роль виртуальной среды в развитии профессиональной компетентности спеииалиста / А.В. Тумалев // Глобальный экономический кризис: реалии и пути преодоления»: сб. науч. ст. - СПб.: Ин-т бизнеса и права, 2009. - С. 515-521.

19. Интернационализация высшего образования: общче конщепџии и некоторые заблуждения с ними связанные / Е.М. Важничая, Т.А. Девяткина, А.Е. Девяткин и др. // Світ медицини та біологіi. - 2013. - № 2-1 (37). - С. 033-035.

20. Yang, $R$. University internationalization: Its meanings, rationales and implications / R. Yang // Intercultural Education. - 2002. - № 13(1). - P. 89-95.

Подгорбунских Анастасия Александровна, кандидат педагогических наук, доцент кафедры славяно-германской филологии, Шадринский государственный педагогический университет, г. Шадринск, aapodgorbunskikh@mail.ru.

Поступила в редакцию 30 апреля 2017 2.

\section{ОБРАЗЕЦ ЦИТИРОВАНИЯ}

Podgorbunskikh, A.A. Internationalization of Educational Activity Through Lingvocultural Competence of Students of Higher Educational Establishments as an Indicator of Quality of Education / A.A. Podgorbunskikh // Вестник ЮУрГУ. Серия «Образование. Педагогические науки». - 2017. - Т. 9, № 3. - C. 78-84. DOI: $10.14529 /$ ped 170308

\section{FOR CITATION}

Podgorbunskikh A.A. Internationalization of Educational Activity Through Lingvocultural Competence of Students of Higher Educational Establishments as an Indicator of Quality of Education. Bulletin of the South Ural State University. Ser. Education. Educational Sciences. 2017, vol. 9, no. 3, pp. 78-84. DOI: $10.14529 /$ ped 170308 